\title{
GENETIC ANALYSIS OF RESISTANCE TO SOYBEAN RUST DISEASE
}

\author{
M. KIRYOWA, P. TUKAMUHABWA and E. ADIPALA ${ }^{1}$ \\ Department of Crop Science, Faculty of Agriculture, Makerere University, P. O. Box 7062, Kampala, Uganda \\ ${ }^{1}$ Regional Universities Forum for Capacity Building in Agriculture, Makerere University, \\ P. O. Box 7062, Kampala, Uganda
}

(Received 18 November, 2008; accepted 23 July, 2009)

\begin{abstract}
Soybean rust (Phakopsora pachyrhizi Sydow.) causes the most damage of all the pathogens known to attack soybean (Glycine max. Merril). A study was conducted in Uganda to estimate the magnitude of genetic parameters controlling soybean rust resistance and to estimate narrow sense heritability of the resistance. Soybean crosses were made and progenies analysed according to the North Carolina II mating design with three resistant parents acting as males namely Maksoy 1N, UG5 and GC00138-29; and three susceptible parents acting as females namely Nam 1, Kabanyolo 1 and Wondersoya. $F_{1} s$ and $F_{2} s$ were planted in the field during two rainy seasons (2004 - 2005). Rust severity was scored using a scale of $0-10$. Genetic parameter estimates were $V_{E}=$ $0.86186, \mathrm{~V}_{\mathrm{D}}=0.30145, \mathrm{~V}_{\mathrm{A}}=0.4616, \mathrm{~V}_{\mathrm{P}}=1.6248$ and $\mathrm{V}_{\mathrm{G}}=0.763$. Resistance gene for rust expressed complete dominance with $\checkmark 4 \mathrm{~V}_{\mathrm{D}} / 2 \mathrm{~V}_{\mathrm{A}}=1.1$. Broad sense heritability $\left(h_{b}{ }^{2}\right)$ was 0.5 , while narrow sense heritability, $h_{n}{ }^{2}$, derived from parameter estimates as a ratio of Additive Variation to Phenotypic variation $\left(V_{A} / V_{p}\right)$, was 0.3 . Environmental variation contributed most (53\%) to total variation $\left(\mathrm{V}_{\mathrm{p}}\right)$ due to high "within families component of variance, $\mathrm{V}_{\mathrm{E}}$ " at $\mathrm{F}_{2}$ generation, which accounts for the low heritability estimates. General Combining Ability (GCA) and Specific Combining Ability (SCA) were significant with the parent GC00138-29 having the lowest GCA value (-0.488) making it the best combiner that can be used in breeding programs for resistance to soybean rust. The cross GC00138-29 x Wondersoya had the lowest SCA value (-0.18) suggesting that it would produce the most highly resistant hybrid offsprings.
\end{abstract}

Key Words: Genetic parameters, Glycine max., specific combining ability, Phakopsora pachyrhizi

\section{RÉSUMÉ}

La rouille du soja (Phakopsora pachyrhizi Sydow.) cause plus de dommage que tout les agents pathogènes connus qui attaquent le soja (Glycine max. Merril). Une étude avait été menée en Ouganda pour estimer l'ampleur de paramètres génétiques contrôlant la résistance contre la rouille du soja dans les soja et estimer l’héritabilité de la résistance au sens restreint. Les croisements du soja avait été faites et les progenies analysés selon le modèle de croisement Nord CarolineII avec trois parents résistants servant des mâles, à savoir Maksoy 1N, UG5 et GC00138-29; et trois susceptibles parents servant des femelles à savoir Nam1, Kabanyolo1 et Wondersoya. $\mathrm{F}_{1} \mathrm{~s}$ et $\mathrm{F}_{2} \mathrm{~S}$ avaient été plantés dans le champ pendant deux saisons pluvieuses (2004-2005). La séverité de la rouille a été indiquée en utilisant une échelle de $0-10$. Les paramètres génétiques estimés étaient $V_{\mathrm{E}}=0,86186, \mathrm{~V}_{\mathrm{D}}=$ $0,30145, \mathrm{~V}_{\mathrm{A}}=0,4616, \mathrm{~V}_{\mathrm{P}}=1,6248$ et $\mathrm{V}_{\mathrm{G}}=0,763$. Le gène de résistance à la rouille exprimé complète la dominance avec “P4VD/ 2VA = 1,1. L'héritabilité au sens large $\left(h_{b}{ }^{2}\right)$ était de 0,5 tandis que l'héritabilité au sens restreint, $h_{n}{ }^{2}$, dérivée de paramètre estimé comme un ratio de la variation additive à la variation phénotypique $\left(\mathrm{V}_{\mathrm{A}} / \mathrm{V}_{\mathrm{p}}\right)$, était 0,3 . La variation de l'environnement a plus contribué $(53 \%)$ à la variation totale $\left(\mathrm{V}_{\mathrm{p}}\right)$ en raison d'une haute “ composant de variance au sein des familles, $\mathrm{V}_{\mathrm{E}}$ ” à la génération $\mathrm{F}_{2}$, qui compte pour les estimations de faible héritabilité. L’Abilité de combinaison générale (GCA) et l'abilité de combinaison spécifique (SCA) avaient été significatives avec le parent GC00138-29 ayant la valeur de GCA plus bas $(-0,488)$, le rendant meilleur combinant qui peut être mieux utilisé dans un programme d'amélioration pour la résistance à la rouille du soja. Le croisement 
GC00138-29 x Wondersoya avait la plus faible valeur SCA $(-0,18)$, suggérant qu'il entraînerait la production d’hybrides hautement résistants.

Mots Clés: Paramètres génétiques, Glycine max., l’abilité de combinaison spécifique, Phakopsora pachyrhizi

\section{INTRODUCTION}

Soybean rust (Phakopsora pachyrhizi: Sydow.) causes the most damage of all the pathogens known to attack soybean (Bromfield, 1984). In Uganda, the disease was first observed in 1996 at National Crops Resources and Research Institute (NaCRRI), in central Uganda. Thereafter, it spread to farmers' fields throughout the country (Tukamuhabwa et al., 2001) and has become endemic in almost all regions of Uganda (Kawuki et al., 2003). Tukamuhabwa and Dashiell (1999) observed a yield loss of 15 - 41\%, and later a yield loss of $60-90 \%$ was reported by the Uganda Seed Project (Anon, 2000). However, yield reductions may vary from negligible to $100 \%$ depending on prevailing conditions (Hinson and Hartwig, 1977; Bromfield, 1984; Tschanz and Shanmugasundaram, 1985).

Kawuki et al. (2003) screened soybean germplasm for rust resistance at the NaCRRI and found none of the screened materials to be immune to rust infection. They observed that 8 were resistant, 45 moderately susceptible, 31 susceptible and 112 very susceptible. Of the eight resistant materials, only UG-5 exhibited resistance trait under advanced field testing. Most of the genotypes were rated as moderate and susceptible; they later deteriorated to susceptible and very susceptible categories with further crop growth. Therefore, the incorporation of durable soybean rust resistance into agronomically desirable and high yielding varieties is still a goal actively pursued in soybean breeding programmes.

Soybean rust resistance is controlled by a single dominant gene (Hartwig, 1986; Tan et al., 1991; Kiryowa et al., 2005). Four single dominant genes for specific resistance to $P$. pachyrhizi have been identified in different cultivars as Rpp1 (Mclean and Byth, 1980); Rpp2, (Bromfield and Hartwig, 1980), Rpp3 (Bromified and Hartwig, 1980; Hartwig and Bromfield, 1983) and Rpp4 (Hartwig, 1986). There have been reports of cultivars with more than one gene controlling resistance with epistatic effects contrary to the widely reported single gene inheritance (Sumarno and Sudjadi, 1977; Mclean and Byth, 1980). This raises the need for further investigation of the genetics of resistance to soybean rust.

The most efficient breeding procedure to enable selection of superior genotypes in selfpollinating crops like soybean depends on the magnitude of additive genetic variance of trait of interest. Thus, narrow sense heritability, $h^{2}$, can form a strong and reliable genetic parameter on which to base a breeding procedure in soybeans (Kearsy and Pooni, 1996).

The heritability of resistance to soybean rust, however, is not well documented in literature. Falconer (1989) reported that $h^{2}{ }_{n}$ can be achieved by parent-offspring regression if parental values are means for both parents. Brim and Hanson (1961) and Fehr (1987) suggested use of expected mean squares from analysis of variance of progenies of interest, to estimate heritability. Lavett (1993) reported that $h^{2}$ is of much importance to plant breeders since low estimates indicate that only a small fraction of trait of interest will be reflected in the next generation, whereas larger estimates indicate that the character will respond to selection easily. Griffiths et al. (1997) attributed the low $h^{2}{ }_{n}$ estimates to the small amount of additive variance compared to dominance interaction. Estimating these genetic parameters will give breeders a picture of which selection methods to employ to ensure higher genetic transfers from parents to offspring.

The objective of this study, therefore, was to estimate the magnitude of genetic parameters controlling soybean rust resistance in soybeans and to estimate narrow sense heritability of the resistance.

\section{MATERIALS AND METHODS}

Experiments were carried out at Makerere University Agricultural Research Institute Kabanyolo (MUARIK), in Wakiso District of Central Uganda. Six soybean genotypes, fully 
characterised for resistance to soybean rust, were used as parents (Table 1).

Hybridisation and progeny assessment. During the first season of 2004 (2004A), staggered planting of the parents was done in order to synchronise flowering dates for easy and successful crossing. The parents were planted in pots in a screen house. At flowering, crosses were made in the screen house using the North Carolina II mating design (Comstock and Robinson, 1952) in which the resistant varieties acted as the male parents and the susceptible ones as the female parents for the full sib and half sib offspring. Reciprocal crosses were also made to study maternal effects. $F_{1}$ seed was harvested, dried and planted in the field during the second season of 2004 (2004B). Rust inoculation occurred naturally and varieties Nam 1 and Wondersoya were planted along the boarders as spreader rows to maximise rust inoculation.

Rust severity was assessed at pod and full seed formation using a scale of $0-10$ where; $0=$ Immune, $1-4.9=$ Resistant and $5-10=$ Susceptible. This was a modification of the $1-5$ scale of the Asian Vegetable Research Development Center (AVRDC, 1977). The plants were scored across the three canopies (top, middle and bottom) and the average recorded (Yang, 1977).

$\mathrm{F}_{2}$ seed was harvested, dried and planted at the onset of the first rains of 2005 (2005A), in the field at a spacing $60 \mathrm{~cm} \times 20 \mathrm{~cm}$. A single $F_{1}$ plant was selected and advanced to form an $\mathrm{F}_{2}$ family. Rust severity was assessed as described above at pod and full seed formation. The $\mathrm{F}_{2}$ populations used included Maksoy 1N x Wondersoya,
Wondersoya x Maksoy 1N, Kabanyolo 1 x UG5, UG5 x Kabanyolo 1, Maksoy 1N x Nam 1, Nam 1 x Maksoy 1N, GC00138-29 x Kabanyolo 1, Kabanyolo 1 x GC000138-29, UG5 x Wondersoya and UG5 $x$ Nam 1. Each plant in each family was assessed for rust severity.

Partitioning of variance. Partitioning of variance and parameter estimation were carried out using the North Carolina II mating design (Comstock and Robinson, 1952). The ANOVA was adopted according to Kearsey and Pooni (1996). Data analysis was carried out using GenStat 7.1 (Lawes Agricultural Trust, 2003)

Assumptions (a) There is no epistasis; and (b) Variance effects due to common environmental effects of families $\left(\mathrm{V}_{\mathrm{EC}}\right)$ is negligible

\section{RESULTS AND DISCUSSION}

Partitioning of variance. The ANOVA for rust severity of $\mathrm{F}_{2}$ families is presented in Table 2 . The variation due to "between female Half-Sib (HS) family groups" was low and non-significant $(\mathrm{P} \geq 0.05)$; whereas variations due to "between male HS family groups" and "interaction between male and female HS family groups” were highly significant $(\mathrm{P}<0.01)$. This implies that General Combining Ability and Specific Combining Ability were relatively important in the inheritance of soybean rust resistance. Therefore, additive and dominance gene effects were significant. GCA was twelve times as large as the SCA, suggesting the dominant role of additive gene effects (Osiru et al., 2001).

Individual GCA estimates are presented in Table 3. Negative and lower GCA effect was

TABLE 1. Parental soyabean genotypes, their pedigree and origin

\begin{tabular}{llll}
\hline Genotype & Pedigree & Origin & Response to rust \\
\hline Maksoy 1N & TGX1835-10E & Nigeria & Resistant \\
GC00138-29 & $($ CH\#1 x Anoka $) \times($ Clarke $63 \times 64.4)$ & Taiwan & Resistant \\
UG5 & - & Uganda & Resistant \\
Kabanyolo1 & Mutant of Clark 63 & Uganda & Susceptible \\
Nam 1 & Hales X P1307-861 & Colombia & Susceptible \\
Wondersoya & - & Nigeria & Susceptible \\
\hline
\end{tabular}


TABLE 2. ANOVA for North Carolina II mating design

\begin{tabular}{lrrrrr}
\hline Source of variation & d.f & \multicolumn{1}{c}{ S.S } & \multicolumn{1}{c}{ m.s } & \multicolumn{1}{c}{ F } & \multicolumn{1}{c}{ ems } \\
\hline Between female HS family groups $(\mathrm{F})$ & 14 & 35.2875 & 2.52054 & $1.43 \mathrm{n} . \mathrm{s}$ & 2.5206 \\
Between Male HS family groups $(\mathrm{M})^{\mathrm{b}}$ & 14 & 304.9371 & 21.78122 & $12.33^{\star}$ & 21.7813 \\
F x Mc $^{\mathrm{c}}$ & 196 & 346.1739 & 1.76619 & $2.05^{\star}$ & 1.7662 \\
Within FS families & 450 & 387.8361 & 0.86186 & & \\
& & & & & \\
Total & 674 & 1074.2346 & & & \\
\hline
\end{tabular}

d. $f=$ degrees of freedom, $s s=$ sum of squares, $F=F$-statistic, ems = expected mean squares. ${ }^{a}$ Analysis of variance; $n$.s not significant at $\mathrm{P} d$ " 0.05; * Significant at $\mathrm{P}=0.01 ;{ }^{\mathrm{b}} \mathrm{GCA} ;{ }^{\mathrm{c}} \mathrm{SCA}$

desirable for resistance in this study because it indicated a larger contribution towards resistance; while positive values suggested a contribution towards susceptibility (Lokko et al., 2004). The parent GC00138-29 had the lowest negative GCA value (-0.49), followed by UG5 $(-0.12)$ and Maksoy 1N (-0.06). On the other hand, the parent Wondersoya had the highest positive GCA (0.42) followed by Kabanyolo 1 (0.24) and Nam 1 (0.08). This implies that GC00138-29 was the best general combiner for resistance to soybean rust and its use in breeding programmes would produce progenies with increased resistance (Lokko et al., 2004). Wondersoya was the worst general combiner because of its highly positive GCA value. If used in hybridisation programmes, its progenies would show increased susceptibility to soybean rust (Osiru et al., 2001).

Negative SCA effects were also desirable for resistance. The cross GC00138-29 x Wondersoya had the most negative SCA value (-0.18), followed by GC00138-29 x Nam 1 (-0.08) (Table 4). These particular crosses would be useful in breeding programmes, for resistance to soybean rust (Lokko et al., 2004)

Parameter estimates affecting resistance to soybean rust are presented in Table 5. Variation due to genotype, $V_{G}$, was high and contributed $47 \%$ of the total phenotypic variation, $V_{P}$. Additive effects contributed $28 \%$ to total variation, $V_{p}$, while dominance effects contributed $19 \%$. This implies that only $28 \%$ of the $V_{P}$ was passed on to the offspring. Environmental variation was the highest contribution (53\%) to total variation. The high magnitude of environmental variation could have been due to non-uniform and inadequate disease pressure (Snijders, 1989).

Resistance was completely dominant using estimates derived from variance partitioning $\left(\checkmark 4 V_{D} / 2 V_{A}=1.1\right)$, which is in agreement with earlier observations by Kiryowa et al. (2005) through ratio analysis, that resistance to soybean rust is controlled by single dominant gene.

TABLE 3. GCA estimates for soybean rust severity on the parents

\begin{tabular}{lc}
\hline Male parent & GCA estimate \\
\hline GC00138-29 & -0.49 \\
UG5 & -0.12 \\
Maksoy 1N & -0.06 \\
Nam 1 & 0.08 \\
Wondersoya & 0.42 \\
Kabanyolo 1 & 0.24 \\
\hline
\end{tabular}

$\mathrm{GCA}=$ General Combining Ability

TABLE 4. SCA estimates for soybean rust severity

\begin{tabular}{lc}
\hline Cross & SCA estimate \\
\hline Maksoy 1N x Wondersoya & 0.10 \\
Maksoy 1N x Nam 1 & 0.04 \\
UG5 x Wondersoya & 0.05 \\
UG5 x Nam 1 & 0.01 \\
UG5 x Kabanyolo 1 & -0.02 \\
GC00138-29 x Wondersoya & -0.18 \\
GC00138-29 x Nam 1 & -0.08 \\
GC00138-29 x Kabanyolo 1 & 0.31 \\
\hline
\end{tabular}

SCA = Specific Combining Ability 
TABLE 5. Estimates of variances and genetic parameters affecting resistance to soybean rust in $\mathrm{F}_{2}$ populations

\begin{tabular}{ll}
\hline Parameter & Value \\
\hline Phenotypic variance $\left(\mathrm{V}_{\mathrm{p}}\right)$ & 1.625 \\
Genotypic variance $\left(\mathrm{V}_{\mathrm{G}}\right)$ & 0.763 \\
Additive variance $\left(\mathrm{V}_{\mathrm{A}}\right)$ & 0.462 \\
Non-additive (dominance) variance $\left(\mathrm{V}_{\mathrm{D}}\right)$ & 0.302 \\
Environment component of within family variance $\left(\mathrm{V}_{\mathrm{E}}\right)$ & 0.862 \\
Variance component due to maternal effects $\left(\mathrm{V}_{\mathrm{EM}}\right)$ & 0.116 \\
Broad sense heritability $\left(\mathrm{h}_{\mathrm{b}}^{2}\right)$ & 0.5 \\
Narrow sense heritability $\left(\mathrm{h}_{\mathrm{n}}^{2}\right)$ & 0.3 \\
Dominance ratio (“4 $\left.4 \mathrm{~V}_{\mathrm{D}} / 2 \mathrm{~V}_{\mathrm{A}}\right)$ & 1.1 \\
\hline
\end{tabular}

Maternal influence was absent since the mean square ratio of the females to that of the males $\left(\mathrm{V}_{\mathrm{EM}}\right)$ was less than one (Mather and Jinks, 1982).

Broad sense heritability was 0.5 , while the narrow sense heritability was 0.3 . The low heritability values could have arisen as a result of the high magnitude (53\%) of the environmental variance (Simmonds, 1981; Fehr, 1987a; Falconer, 1989). The high environmental variance could have resulted from determination heritability using highly segregating $\mathrm{F}_{2}$ populations. This was reflected in the very high 'within Full-sib (FS) families' component of variation. The low heritability estimate also means that more effective selection methods should be used to ensure considerable genetic gain of resistance in the advanced generations of the populations used in the study.

Heritability of a character, however, is not constant and the decisions made by a breeder can influence the magnitude of heritability and the amount of genetic improvement obtained from selection (Falconer, 1989). In order to minimise the magnitude of the environment variation, Snijders (1989) recommended that breeders should ensure a uniform and adequate disease pressure in the field, which will contribute to successful selection. For characters with low narrow sense heritability estimates ranging between 0.25 and 0.10 , Casali and Tigchelaar (1975) recommended bulk breeding and single seed descent methods in order to maximise heritable genetic variation in the offspring populations. Jinks and Pooni (1984) recommended that in order to increase genetic gain; selection should be delayed further into the inbreeding programme.

\section{CONCLUSION}

A single dominant gene is responsible for resistance to soybean rust. Additive-dominance model adequately explains the observations made. Both additive and dominance effects are important in determining resistance to soybean rust resistance. Narrow sense heritability is relatively low due to the high environmental variation resulting from high within-families variance $\left(\mathrm{V}_{\mathrm{E}}\right)$. It is recommended that further studies of heritability be carried out at more advanced generations $\left(\mathrm{F}_{3}-\mathrm{F}_{6}\right)$. The parent GC00138-29 would yield highly resistant offspring and is, therefore, recommended for use in breeding for resistance to soybean rust disease in soybean programmes.

\section{ACKNOWLEDGEMENTS}

This study was funded by Makerere University, and the Regional Universities Forum for Capacity Building in Agriculture (RUFORUM). The authors also thank the National Agricultural Research Organization for providing the soybean materials used.

\section{REFERENCES}

Anonymous, 2000. Soybean rust disease. A report to the National Agricultural Research Organization. Uganda Seed Project, 2000. 
Asian Vegetable Research and Development Centre (AVRDC). 1977. Soybean report. 75. Shanhwa, Taiwan, Republic of China.

Brim, C. and Hanson, D. 1961. Early generation testing of diallel crosses of soybean. Crop Science 1: $187-190$.

Bromfield, K.R. and Melching, J.S. 1982. Sources of specific resistance to soybean rust (Abstr). Phytopathology 72: 706.

Bromfield, K.R. and Hartwig, E.E. 1980. Resistance to soybean rust and mode of resistance. Crop Science 20: 254-255.

Casali, V.W.D. and Tigchelaar, E.C. 1975. Computer simulation studies comparing pedigree, bulk and single seed descent in self pollinated populations. Journal of American Society of Horticultural Sciences 100: 364-367.

Comstock, R.E. and Robinson, H.F. 1952. Estimation of average dominance of genes, in Heterosis. Gowen, J.W. (Ed.), pp. 494-516. Iowa State College Press, Ames, Iowa, USA.

Falconer, W.R. 1989. Introduction to Quantitative Genetics. $3^{\text {rd }}$ Ed. Wiley, N.Y. USA.

Fehr, W.R. 1987. Principles of Cultivar Development. Vol 1 . Theory and Techniques. McGraw - Hill Inc. New York, USA.

Griffiths, A.J.F, Miller, J.H, Suzuki, T.D, Lewontin, R.C and Gilbert, W.M. 1997. An introduction to Genetic Analysis. W.H. Freeman and Co. N.Y.USA.

Hartwig, E.E. 1986. Identification of a fourth gene conferring resistance to soybean rust. Crop Science 26: 1135-1136.

Hartwig, E.E. and Bromfield, K.R. 1983. Relationship among three genes conferring specific resistance to rust in soybeans. Crop Science 23:237-239.

Hinson, K. and Hartwig, E.E. 1977. Soybean production in the tropics. FAO Plant Production and Protection Paper No. 4. AGPS MISC/35. FAO, Rome, Italy.

Jinks, J.L. and Pooni, H.S. 1984. Comparison of inbred lines produced by single seed descent and pedigree inbreeding. Heredity 53: 299308

Kawuki, R.S., Adipala, E., Lamu, J. and Tukamuhabwa, P. 2003. Responding to the soybean rust epidemic. African Crop Science Journal 4:301-318.
Kearsey, J. Michael and Pooni, S. Harpal. 1996. The Genetical Analysis of Quantitative Traits. $1^{\text {st }}$ Ed. Chapman and Hall. Boundary Row, London, UK.

Kiryowa, M., Tukamuhabwa, P. and Adipala, E. 2005. Inheritance of resistance to soybean rust; Phakopsora pachyrhizi. African Crop Science Society Conference Proceedings 7:257-260.

Lavett, D.K. 1993. An Introduction to Genetic Analysis. $5^{\text {th }}$ Ed. W.H Freeman and Company. N.Y.USA.

Lokko, Y., Dixon, A, Offei, S.K. and Danquah, E.Y. 2004. New directions for a diverse planet. Proceedings of the fourth International Crop Science Congress. Brisbane, Australia. 26 $6^{\text {th }}$ September - $1^{\text {st }}$ October 2004.

Mather, K. and Jinks, J.L. 1982. Biometrical Genetics. $3^{\text {rd }}$ edition, Chapman and Hall, London, UK.

Mclean, R.J. 1981. Studies of resistance in soybean (Glycine max) to rust (Phakopsora pachyrhizi Syd.) PhD. Thesis, University of Queensland, Brisbane St. Lucia, Australia. 255pp.

Mclean, R.J. and Byth, D.E. 1980. Inheritance of resistance to rust Phakopsora pachirhizi in soybeans. Australian Journal of Agricultural Research 31:951-956.

Osiru, M.O., Rubaihayo, P.R. and Opio, F. 2001. Inheritance of resistance to tomato bacterial wilt and its implication for potato improvement in Uganda. African Crop Science Journal 9: 9-16.

Simmonds, N.W. 1981. Principles of crop improvement. Longman Group Ltd., London, UK.

Snijders, C.H.A. 1989. Response to selection in $\mathrm{F}_{2}$ generation of winter wheat for resistance to head blight caused by Fusarium Culmorum. Kluwer Academic Publishers. Euphytica 50: $163-169$.

Sumarno, R.S. and Sudjadi, M.S. 1977. Breeding for soybean rust resistance in Indonesia. In: Rust of soybeans, the problem and research needs. A Workshop report. International Agricultural Publications. INTSOY Series Number 12: 54-57. 
Tan, Y.J. Sun, Y.L. and Shan, Z.H. 1991. Inheritance of resistance to soybean rust. Soybean Science 2:104-109

Tukamuhabwa, P. and Dashiell, K.E. 1999. Screening soybean germplasm for resistance to rust and evaluation of associated yield loss. Technical Report. National Agricultural Research Organization, Ministry of Agriculture Animial Industry and Fisheries. Government of Uganda.
Tukamuhabwa, P., Dashiell, K.E. and AssafoAdjei. 2001. Determination of yield loss caused by rust Phakopsora pachyrhizi in four genotypes of soybeans. African Crop Science Conference Proceedings 5: 423-426.

Yang, C.Y. 1977. The International Working Group on Soybean Rust (IWGSR) rating system. Soybean rust Newsletter 1:4-6. 